\title{
The Acquisition of Vocabulary by Using Children Song and Kinesthetic Learning Strategy in Bali Public School
}

\author{
Aridna Suhcera $^{1^{*}}$, I Nengah Sudipa ${ }^{2}$, Ni Wayan Sukarini ${ }^{3}$ \\ English Department Faculty of Arts - Udayana University \\ 1[suhceraaridna@gmail.com] ${ }^{2}$ [nengahsudipa@yahoo.co.id] \\ ${ }^{3}$ [wayansukarini@yahoo.co.id] \\ *Corresponding Author
}

\begin{abstract}
Many learning strategies were made in order to enrich children's vocabulary. The present research is aimed at seeing if a great combination of learning strategy could affect children in acquiring vocabulary. The research was using a combination of children song and kinesthetic learning strategy to acquire vocabulary. The subject of the research was the second grade students of Bali Public School with 3 samples from Class A and Class B. Group A was using the combination of children song and kinesthetic learning strategy and Group B was using children song alone without kinesthetic learning strategy. The data were obtained through pretest and post-test that consist of multiple choice questions. The obtained data were analyzed quantitatively and qualitatively. Furthermore, the data are presented using formal (words and natural language) and informal (table and diagrams) methods. The vocabulary that the children had acquired through this combination included adjective, verbs, collective nouns and countable nouns. The process of acquiring vocabulary through kinesthetic learning strategy on the second grade students included the symbolic, centration and elimination of egocentrism process.
\end{abstract}

Keywords: Kinesthetic learning strategy, vocabulary, acquisition

\begin{abstract}
Abstrak
Banyak strategi pembelajaran dibuat untuk memperkaya kosa kata anak-anak. Penelitian ini ditujukan untuk melihat jika kombinasi strategi pembelajaran dapat mempengaruhi anak-anak dalam memperoleh kosa kata. Penelitian ini menggunakan kombinasi dari lagu anak-anak dan strategi pembelajaran kinestetik untuk memperoleh kosa kata. Subjek dari penelitian ini adalah murid-murid kelas 2 dari Sekolah Bali Public School dengan 3 sampel dari kelas A dan kelas B. Kelompok A menggunakan kombinasi dari lagu anak-anak dengan strategi pembelajaran kinestetik dan kelompok B hanya menggunakan lagu anak-anak tanpa strategi pembelajaran kinestetik. Data dari penelitian ini diperoleh dari pra-tes dan pasca-tes yang terdiri dari soal pilihan ganda. Data yang sudah diperoleh di analisis secara kulatitatif dan kuantitatif. Selanjutnya, data tersebut disajikan dengan metode formal (kata-kata dan Bahasa) dan metode informal (table dan diagram). Kosa kata yang diperoleh oleh anak-anak melalui kombinasi pembelajran ini adalah kata sifat, kata kerja, kata benda kolektif dan kata benda yang dapat dihitung. Proses dalam memperoleh kosa kata melalui strategi pembelajaran kinestetik pada murid-murid kelas dua meliputi proses simbolisasi, pemusatan dan pengeleminasian dari egosentrisme.
\end{abstract}

Kata kunci: strategi pembelajaran kinestetik, kosa kata, akuisisi

\section{Background of the Study}

Vocabulary has a great role in mastering a language or learning a new language. We cannot separate our needs of vocabulary in our daily conversation. Vocabulary is considered to be the most important component when it comes to learning English as a foreign language. 
Children, especially $2^{\text {nd }}$ grade students mostly energetic and often difficult to focus in such a long time. Eric Jensen (2005) in his book entitled "Teaching with the brain in Mind 2nd edition" stated that movements or gestures will help blood circulation that helps distribute oxygen effectively to the brain. However, connection between learning and movement often dismiss once the students reached $1^{\text {st }}$ and beyond $2^{\text {nd }}$ grade. The $2^{\text {nd }}$ grade students were chosen for this research because at this current stage the students have learnt to read and write as well. Bali Public School was chosen for data collection because of the reason of being effective and the curriculum that applied in this school is National Plus curriculum in which English has an important role in teaching-learning process. Therefore, they valued the learning strategy that could help and develop students in expressing their idea better.

\section{Problem of the Study}

a. What kind of vocabulary acquired by the children through children song and kinesthetic learning strategy?

b. How do they acquire vocabulary using the combination of children song and kinesthetic learning strategy?

\section{Aims of the Study}

a. To find out what kind of vocabulary that the children acquire after applying children song and kinesthetic learning strategy.

b. To analyze the process of acquiring vocabulary using the combination of children song and kinesthetic learning strategy.

\section{Research Method}

The research method used in this study is divided into three points. The first point was how the data were collected, the second point was how the data were analyzed and the third point was how the data analysis was presented.

\subsection{Data Source}

Data source refers to the object from which the data were taken. The data used in this writing were taken from the students of Bali Public School in Denpasar. The students were chosen in this study were in $2^{\text {nd }}$ grade from Class A and Class B.

\subsection{Method and Technique of Collecting Data}

The method used in collecting data was the Quasi-Experimental Research by Cook \& Campbell (1979) in Pretest-Posttest Design. The research measured the level of vocabulary mastery before applying the learning strategy and after the learning strategy applied for 3 meetings. Class 2A was given kinesthetic learning strategy with children song while class 2B was not given the kinesthetic learning strategy and only with children song.

\subsection{Method and Technique of Analyzing Data}

In analyzing the data, the data were quantitatively and qualitatively analyzed by looking at the way students responded to kinesthetic learning strategy as stimuli. After the data were collected and analyzed, they were presented in a table with score of correct answer and score with incorrect answer. The data were analyzed using the formula proposed by Stamboel (1982).

\subsection{Method and Technique of Presenting Data Analysis}

In presenting the data analysis, the data are presented using Sudaryanto (1993:145) methods which are formal (words and natural language) and 
informal (diagram, tables or artificial language).

\section{Analysis}

\subsection{The Result of Pre-Test}

The pre-test was given in the multiple choice test in which the test contains 19 words. The words included the kind of animals, emotions, body parts and activities. Students must identify the animals, emotions, body parts and activities from the pictures and cross the correct answer. The data obtained from the pre-test were described and analyzed in term of the number of words answered correctly and the number of words answered incorrectly.

Table I: The data obtained from the pretest of Group A (Kinesthetic approach)

\begin{tabular}{|c|c|c|c|c|}
\hline Students & $\begin{array}{l}\text { Num } \\
\text { word } \\
\text { answ } \\
\text { corre }\end{array}$ & $\begin{array}{l}\text { er of } \\
\text { red } \\
\text { tly }\end{array}$ & $\begin{array}{l}\text { Nun } \\
\text { wor } \\
\text { ans } \\
\text { inco }\end{array}$ & $\begin{array}{l}\text { ber of } \\
\text { ls } \\
\text { ered } \\
\text { rectly }\end{array}$ \\
\hline Ananda & 16 & $84.2 \%$ & 3 & $15.8 \%$ \\
\hline Christian & 14 & $73,7 \%$ & 5 & $26.3 \%$ \\
\hline Ayu & 17 & $89.5 \%$ & 2 & $10.5 \%$ \\
\hline Mean & 15.6 & $82.5 \%$ & 3.3 & $17.5 \%$ \\
\hline Predicate & \multicolumn{2}{|c|}{ Very Good } & & \\
\hline
\end{tabular}

Table II: Data obtained from the pre-test of Group B (Non-kinesthetic approach)

The result of the pre-test shows that both groups had great vocabulary basis. It was shown in the percentage of the correct answers of each group. For Group A, the correct answer is $80.7 \%$ and Group B is $82.5 \%$. The percentage of incorrect answers of Group A is $19.3 \%$ and Group B is $17.5 \%$.

\subsection{Result of Teaching and Observation}

\subsubsection{First Teaching}

\begin{tabular}{|l|l|l|l|l|}
\hline Students & \multicolumn{2}{|l|}{$\begin{array}{l}\text { Number of } \\
\text { words } \\
\text { answered } \\
\text { correctly }\end{array}$} & \multicolumn{2}{|l|}{$\begin{array}{l}\text { number of } \\
\text { words } \\
\text { answered } \\
\text { incorrectly }\end{array}$} \\
\hline Satriya & 16 & $84.2 \%$ & 3 & $15.8 \%$ \\
\hline Bima & 14 & $73,7 \%$ & 5 & $26.3 \%$ \\
\hline Devastya & 16 & $84.2 \%$ & 3 & $15.8 \%$ \\
\hline Mean & 15.3 & $80.7 \%$ & 3.6 & $19.3 \%$ \\
\hline Predicate & \multicolumn{2}{|l|}{ Very Good } & & \\
\hline
\end{tabular}

\section{Group A}

In the first meeting, 'Happy Song' was introduced to the students. The actions or movements were introduced to the children when they heard the words clap, stomp, 'oh no!' and take a nap. Then, students were asked to move and sing according to the song and children must copy the movements that were introduced with special instructions for a certain word that pop up in the song. Although this was our first meeting, students were excited and showed a lot of enthusiasm during the process. The students were excited and happily sang and dance when the song played. After the words they had learnt being recalled and most of them had memorized them correctly.

\section{Group B}

For this group, there was no kinesthetic learning strategy that was involved in the process. Same words and song as group A were introduced to the students in group B. However, when they sang the song, students were not moving along with the song and only sang the song from their seats. Some of the 
students could not resist creating their own movement when they sang the song from their seats. After the words they had learnt being recalled, most of them had memorized it correctly.

\subsubsection{Second Teaching}

\section{Group A}

In the second teaching, verbs and nouns were introduced to the children. Before introducing the song, the words that they had learnt in the first meeting were being recalled. Furthermore, the researcher asked if they had visited the aquarium before and if they had seen seahorse, jellyfish, turtle, octopus, baby shark and blue whale. Some of the students who had visited the aquarium were asked to come in front of the class to describe the physical features of the animals. Therefore, the others who had not been to the aquarium could visualize the animals. 'A Sailor Went to Sea' song was introduced to the students. One of the students who was very active in the class was asked to come in front of the class as the example to the others. His name is Bima and he was guided by the researcher to move and everyone must copy the movement from him correctly. The students were happily singing and dancing according to the song.

\section{Group B}

For the second meeting, the same vocabulary and song as group A were introduced to group B. Before the song was introduced, the words that they had learnt in the first meeting were being recalled. Then, the researcher asked if they had visited the aquarium before and if they had seen seahorse, jellyfish, turtle, octopus, baby shark and blue whale. Some of the students who had visited the aquarium were asked to come in front of the class to describe the physical features of the animals to help the others visualize the mentioned animals.
The students must memorize the animals' arrangement from the song. Some of the students sang along with the song. When the song ended, some students were pointed according to the seating line and mentioned the animals' arrangement according to their line. So the students that got point first must have mentioned the name of the animal that firstly pop in the song and it kept going until the last line. The words that they had learnt were recalled, and they managed to memorize the words correctly and mentioned the animals' arrangement in the song correctly.

\subsubsection{Third Teaching}

\section{Group A}

In the last meeting, nouns were introduced. Before the activity, the names of animals that they had learnt in the second meeting were being recalled. Then, the students were asked about the name of body parts. 'One Little Finger' song was introduced to the students. Bima, the student who was asked to come in front of the class as the model for the song in the second meeting volunteered himself to be the model again. This showed that the student got excited to learn and they enjoyed the process very well. The students then, followed the movement happily and they were able to recall all of the body parts correctly.

\section{Group B}

In the second meeting, the same vocabulary and song as group A were introduced to group B. Before the song was introduced, the words that they had learnt in the second meeting were recalled. Then, the students were asked about the name of body parts. The students were asked to point to the body parts mentioned in the song. However, the vision needs to be focused on the 
researcher. The researcher was pointing to the wrong body part that was mentioned in the song and then checked if the students were pointing to the wrong body part as well. The students were having fun and managed to recall the body parts that had been taught correctly.

\subsection{The Result of Post-test}

The post-test was given in terms of the multiple choice test in which the test contains 19 words. The words included the kind of animals, emotions, body parts and activities. Students must identify the animals, emotions, body parts and activities from the pictures and crossed the correct answer. The questions for the post-test were the same as the pretest. The same test was given to see if there was an improvement from the last meeting. Therefore, we could see how much the children improved from the first meeting. The data obtained from the post-test were described and analyzed in term of the number of words answered correctly and the number of words answered incorrectly. The result of the post-test showed that both groups had improvement. It was shown in the percentage of the correct answer of each group. For Group A, the correct answer is $94.7 \%$ and Group B is $85.9 \%$. The percentage of incorrect answer of Group $A$ is $5.3 \%$ and Group B is $14 \%$. The improvement from Group A was significant from the last meeting and manage to have 'Excellent' predicate. Group B, on the other hand, remain to be the same as 'Very Good' predicate.

The other students from Group A had shown great improvement as well, the numbers of students who were able to answer all of the questions correctly had increased from 3 into 5 students and with the average of incorrect answers of 1 mistake instead of 3 or 2. Group B did not show significant improvement and remain with the average incorrect answers with 2 mistakes instead of 3 or 4 mistakes. Most of the students made a small mistake in several questions related to animals, verbs, and body parts

Table III: Data obtained from the posttest of Group A (Kinesthetic approach)

\begin{tabular}{|c|c|c|c|c|}
\hline Students & & $\begin{array}{l}\text { ber of } \\
\text { s } \\
\text { ered } \\
\text { ctly }\end{array}$ & & $\begin{array}{l}\text { lber of } \\
\text { ds } \\
\text { vered } \\
\text { rrectly }\end{array}$ \\
\hline Satriya & 18 & $94.7 \%$ & 1 & $5.3 \%$ \\
\hline Bima & 17 & $89.5 \%$ & 2 & $10.5 \%$ \\
\hline Devastya & 19 & $100 \%$ & 0 & $0 \%$ \\
\hline Mean & 18 & $94.7 \%$ & 1 & $5.3 \%$ \\
\hline Predicate & \multicolumn{2}{|c|}{ Excellent } & & \\
\hline
\end{tabular}

Table IV: Data obtained from the posttest of Group B (Non-kinesthetic approach)

\begin{tabular}{|l|l|l|l|l|}
\hline Students & \multicolumn{2}{|l|}{$\begin{array}{l}\text { Number of } \\
\text { Words } \\
\text { Answered } \\
\text { Correctly }\end{array}$} & \multicolumn{2}{|l|}{$\begin{array}{l}\text { Number of } \\
\text { Words } \\
\text { Answered } \\
\text { Incorrectly }\end{array}$} \\
\hline Ananda & 16 & $84.2 \%$ & 3 & $15.8 \%$ \\
\hline Christian & 15 & $78.9 \%$ & 4 & $21 \%$ \\
\hline Ayu & 18 & $94.7 \%$ & 1 & $5.3 \%$ \\
\hline Mean & 16.3 & $85.9 \%$ & 2.6 & $14 \%$ \\
\hline Predicate & \multicolumn{2}{|l|}{ Very Good } & & \\
\hline
\end{tabular}

\subsection{The Comparison of the Results}

The total improvement that group A achieved was $14 \%$. It is proven that the students did acquire vocabulary by using children song and kinesthetic learning strategy. Group B achieved 3.4\% improvement while Group A achieved 
$14 \%$ improvement. We could conclude that group B had some improvement from the first meeting. However, it was not as significant as Group A.

\subsection{The Kinds of Vocabulary That Children Acquired}

The Types of vocabulary that the students had acquired were classified by words classification theory from Ni Putu Sri Ayu Wulandari (2007:17). The types of vocabulary that the students had acquired are as follows:

\section{(1) Adjective}

Words that describe a noun (person, place, etc). From three types of vocabulary (Physical qualities of color or shape, Psychological qualities of emotion and evaluating qualities), types of adjective that the children acquired are psychological qualities of emotions. Words that students had acquired: happy, angry, scared and sleepy.

\section{(2) Verbs}

Verbs generally express action, event, processes, activities, states, etc. Every complete sentence must contain at least one verb. Words that students had acquired: see, swim, clap, stomp and take a nap.

\section{(3) Collective Nouns}

Collective nouns refer to a group of persons or things that are generally thought of as one unit. Words that students had acquired: seahorse, jellyfish, turtle, octopus, baby shark and blue whale.

\section{(4) Countable Nouns}

Countable nouns refer to the names of persons, things, places, or ideas that can be counted. Words that students had acquired: finger, head, nose, chin, arm, leg and foot.

\subsection{The Process of Acquiring Vocabulary Through Kinesthetic Learning Strategy}

The subjects of this research were the second grade students. From Group A, the samples age included 7 and 8 years old. Two students had merely turned 7 years old and one student had turned 8 years old this year. From Group $\mathrm{B}$, the samples age was 7 years old. Based on intellectual theory from Jean Piaget (1972) in Brown (2000:61), the students are in their pre-operatory stage and operational stage (concrete operational stage).

When children used children song and kinesthetic learning strategy, they processed it by using the symbolic and centration process. The creative movements were used to symbolize the words that they heard and when they were focusing to memorize the movement, they did 'centration' where they focused on one stimuli which was the creative movement. The majority of the children were 7 years old and few of them were 8 years old. They were able to use logic in processing the information that they received. Thus, the important cognitive process that played a big role when applying the kinesthetic learning strategy is 'The Elimination of Egocentrism'.

For example, when describing about animals that some of them never had seen it in real life. They tried to visualize them from someone that had already seen it before and made it sound like they had seen it although in reality they had never seen it. They didn't refuse the visualization process and forced their perspective that they had never seen it. Rather, they tried to position themselves and visualize it from someone that had seen it. 


\section{Conclusion}

For Kinesthetic learning strategy is a great strategy for active young learners. This learning strategy not only allows students to learn faster but also helps them develop their cognitive skill. Their imagination also plays a great role in how they imagine something that they have not seen yet and try to visualize it. The result of the test had proven that how some movement can boost their ability to acquire new words. It can be seen from Group A subjects with average score from the pre-test was $80.7 \%$ increase amazingly into the total average score from their post-test was $94.7 \%$. From the research, we could conclude that the students were able to acquire three types of vocabulary from kinesthetic learning strategy. The three types of vocabulary were adjectives, verbs and nouns (collective and countable nouns). The process of acquiring vocabulary through kinesthetic learning strategy on second grade students includes the symbolic, centration and elimination of egocentrism process.

\section{References}

Brown, H. Douglas. 2000. Principles of Language Learning and Teaching. California: Longman.

Cook, T. D., and Campbell, D. T. 1979. Quasi-experimentation: Design \& analysis issues in field settings. Boston, MA: Houghton Mifflin.

Jensen, Eric. 2005. Teaching with the brain in Mind. $2^{\text {nd }}$ ed. Virginia: Assn for Supervision \& Curriculum.

Stamboel, C. S. 1982. Prinsip dan Teknik Pengukuran dalam Dunia Pendidikan. Jakarta: Mutiara.
Sudaryanto. 1993. Metode dan Aneka Tehnik Analisis Bahasa ( Pengantar Penelitian Wahana Kebudayaan secara Linguistik). Yogyakarta: Duta Wacana University Press.

Wulandari, Ayu Sri Putu. 2007. The Ability of Fifth Year Students of SDN 4 Kerobokan in Recalling English Vocabularies Through Kim's Game. Denpasar: Udayana University. 